\title{
Establishment of a Sandwich Enzyme Linked Immunosorbent Assay for Canine Interleukin-8
}

\author{
Amro MOHAMED ${ }^{1,3)}$, Yasunobu MATSUMOTO'), Kazuhiro YOSHIHARA ${ }^{3)}$, Yoshitsugu MATSUMOTO ${ }^{1)}$, Toshihiro \\ WATARI $^{2)}$, Hajime TSUJIMOTO ${ }^{2)}$, Atsuhiko HASEGAWA ${ }^{2)}$, Takashi ONODERA ${ }^{1)}$, and Yoshikazu HIROTA ${ }^{3) *}$ \\ Departments of ${ }^{1)}$ Molecular Immunology and ${ }^{2)}$ Veterinary Internal Medicine, Faculty of Agriculture, The University of Tokyo, Bunkyo- \\ ku, Tokyo 113, and ${ }^{3}$ Laboratory of Immune Cytology, National Institute of Animal Health, Kannondai, Tsukuba, Ibaraki 305, Japan \\ (Received 29 June 1996/Accepted 7 September 1996)
}

ABSTRACT. To estimate canine interleukin-8 (cIL-8) levels in blood plasma samples, a sandwich enzyme linked immunosorbent assay (ELISA) was established. For the development of the sandwich ELISA, polyclonal anti-cIL-8 (capturing), biotinylated anti-cIL-8 (developing) antibodies and glutathione-S-transferase/cIL-8 (GST/cIL-8) fusion protein as an antigen were used. cIL-8 in the fusion protein of GST/cIL-8 was detected in a dose dependent manner. The lowest limit of GST/cIL-8 detectable by this method was $2 \mathrm{ng} / \mathrm{m} l$ of GST/cIL-8 (containing; $0.470 \mathrm{ng} / \mathrm{m} l$ of cIL-8). IL-8 levels in the plasma samples from apparently healthy dogs were less than $0.470 \mathrm{ng} /$ $\mathrm{m} l$. Higher levels of IL-8 were detected in the plasma samples of dogs with cystitis, dermatitis, and gastric cancer. These results suggest that the determination of cIL-8 by the sandwich ELISA is useful in diagnosis of inflammatory diseases in dogs. - KEY wORDS: canine interleukin-8, ELISA, inflammation.

Interleukin-8 (IL-8) is one of important cytokines involved in regulating the immune response and inflammation. To understand the biological role of IL-8 in canine diseases, an appropriate means to detect IL-8 is needed. In general, biological activities of IL- 8 have been evaluated by neutrophil chemotaxis assay $[8,10]$. The concentrations of IL-8 in blood samples and body fluids from humans [5], dogs [7], cattle [2], and rabbits [1] have also been determined by the enzyme linked immunosorbent assay (ELISA) using monoclonal or polyclonal antibodies against IL-8. In clinical aspects, ELISA appears to be more practical than chemotaxis assay, because of some advantages in easy and simple preparation and procedures of its measurement system and its objective evaluation. We previously isolated a molecular clone of canine IL-8 (cIL-8) cDNA and showed that the culture supernatants of Cos7 cells transfected with a cloned cIL- 8 cDNA have a chemotactic factor for canine neutrophils and lymphocytes $[8,10]$ and biological activities inducing glutathione-Stransferase/cIL-8 (GST/cIL-8) driven shape change responses to canine neutrophils $[9,11]$. We also reported the production and characterization of polyclonal anti-cIL-8 antibodies [11]. The present study was carried out to develop the ELISA system for the determination of cIL-8 and to compare the levels of cIL-8 in blood plasma samples from dogs with some different types of diseases.

Polyclonal rabbit anti-cIL- 8 antibodies, purified by affinity column chromatography and confirmed no-reactivity with GST by Western blotting assay as described previously [11], were used. Biotinylation of these antibodies was performed according to the method of Kasahara et al. [4]. In brief, $1 \mathrm{mg}$ of anti-cIL-8 antibodies was dialyzed

* Correspondence to: Dr. Hirota, Y., Laboratory of Immune Cytology, National Institute of Animal Health, 3-1-1 Kannondai, Tsukuba, Ibaraki 305, Japan overnight against $0.1 \mathrm{M} \mathrm{NaHCO}_{3}$ buffer, $\mathrm{pH} 8.0$, and then incubated with $60 \mu \mathrm{g}$ of $\mathrm{N}$-hydroxysuccinimido-biotin (Sigma, St. Louis, MO., U.S.A.) dissolved in dimethylsulphoxide on a shaker for $4 \mathrm{hr}$ at room temperature. Subsequently, the mixture was dialyzed extensively against phosphate buffered saline (PBS; $\mathrm{pH} 7.4$ ) for $60 \mathrm{hr}$. For the determination of the protein content in the biotinylated rabbit anti-cIL- 8 antibodies, its optical density (O.D.) at $280 \mathrm{~nm}$ was measured by a spectrophotometer (Beckman Instrument, Inc., Fullerton, CA, U.S.A.), and they were then kept at $-20^{\circ} \mathrm{C}$.

For the development of a sandwich ELISA for cIL-8, each well of a 96 wells microplate (Immunoplate, Nunc, Roskilde, Denmark) was coated with $100 \mu$ of polyclonal rabbit anti-cIL-8 antibodies (capturing; $4 \mu \mathrm{g} / \mathrm{ml}$ ) in $0.05 \mathrm{M}$ carbonate-bicarbonate buffer, $\mathrm{pH} 9.6$ by incubating overnight at $4{ }^{\circ} \mathrm{C}$. The plate was washed 5 times with 300 $\mu l /$ well of PBS containing $0.05 \%$ Tween-20 (PBS-T), blocked with $200 \mu \mathrm{l} /$ well of PBS containing 1\% BSA (Miles Inc., Kankakee, IL, U.S.A.) for $2 \mathrm{hr}$ at $37^{\circ} \mathrm{C}$, and then washed 5 times with PBS-T. One hundred $\mu l$ of serially diluted GST/cIL-8, GST or undiluted canine plasma samples were applied to each of the coated wells. Ethylene diamine tetraacetic acid (EDTA)-treated blood was taken from 6 apparently healthy dogs (3-5 years old, 4 males and 2 females) and totally 15 patient dogs, and the resulting plasma samples were used for the determination of IL-8 (Tables 1 and 2). After $2 \mathrm{hr}$ incubation at $37^{\circ} \mathrm{C}$, wells were washed 5 times with PBS-T, and $100 \mu l$ of biotinylated developing antibodies $(1 \mu \mathrm{g} / \mathrm{ml})$ were then added to the wells. After $2 \mathrm{hr}$ incubation at $37^{\circ} \mathrm{C}$, wells were similarly washed, and then incubated with horse radish-peroxidase streptavidin (1/1,000), (Zymed Lab., Inc., San Francisco, CA, U.S.A.) for $1 \mathrm{hr}$ at $37^{\circ} \mathrm{C}$. One hundred $\mu \mathrm{l}$ of the substrate solution $(0.01 \%$ of ABTS; Sigma in $50 \mathrm{mM}$ citric acid with $0.003 \% \mathrm{H}_{2} \mathrm{O}_{2}$ ) was added to each well to allow color development at room temperature for $30 \mathrm{~min}$. The 
Table 1. Profiles of examined dogs at the determination of IL-8

\begin{tabular}{|c|c|c|c|c|c|c|c|c|c|c|c|}
\hline & \multirow{2}{*}{$\begin{array}{l}\text { Dog } \\
\text { No. }\end{array}$} & \multirow{2}{*}{ Breed } & \multirow{2}{*}{$\begin{array}{l}\text { Ages } \\
\text { (years) }\end{array}$} & \multirow{2}{*}{ Sex } & \multirow{2}{*}{$\begin{array}{c}\text { Body weight } \\
(\mathrm{kg})\end{array}$} & \multirow{2}{*}{$\begin{array}{l}\text { WBC } \\
\left(\times 10^{3} / \mathrm{m} l\right)\end{array}$} & \multicolumn{4}{|c|}{ Differential (\%) of leukocytes } & \multirow{2}{*}{ Diagnosisa) } \\
\hline & & & & & & & Neutro. & Lymph. & Mono. & Eos. & \\
\hline \multirow[t]{15}{*}{ Patient } & 1 & Shih Tzu & 9 & M & 7.0 & 33.1 & 91.0 & 4.0 & 5.0 & 0.0 & Cystitis \\
\hline & 2 & Shih Tzu & 9 & M & 7.2 & 13.2 & & & $\mathrm{ND}^{\mathrm{b})}$ & & Cystitis \\
\hline & 3 & Shelty & 9 & $\mathrm{~F}$ & 14.7 & 8.5 & 94.0 & 4.0 & 1.0 & 1.0 & Cystitis \\
\hline & 4 & Shih Tzu & 9 & M & 6.7 & 11.0 & & & ND & & Cystitis \\
\hline & 5 & Pug & 8 & $\mathrm{~F}$ & 8.4 & 24.8 & & & ND & & Seborrheic dermatitis \\
\hline & 6 & Chihuahua & 0.3 & $\mathrm{~F}$ & 0.7 & 16.7 & 85.0 & 9.0 & 6.0 & 0.0 & Dermatitis \\
\hline & 7 & Shiba & 1 & M & 8.3 & 13.1 & 86.0 & 14.0 & 0.0 & 0.0 & Ryoderma (dermatitis) \\
\hline & 8 & Shih Tzu & 3 & M & 7.1 & 16.0 & & & ND & & Dermatitis \\
\hline & 9 & Shelty & 9.2 & $\mathrm{~F}$ & 11.9 & 38.0 & 86.0 & 9.0 & 3.0 & 3.0 & Dermatitis \\
\hline & 10 & Shih Tzu & 6 & NM & 8.3 & 21.8 & 94.0 & 6.0 & 0.0 & 0.0 & Chronic dermatitis \\
\hline & 11 & Shih Tzu & 10 & $\mathrm{NF}$ & 4.6 & 29.5 & 80.0 & 10.0 & 6.0 & 4.0 & Chronic gastritis \\
\hline & 12 & Mongrel & 12 & NM & 18.2 & 9.9 & 80.0 & 19.0 & 0.0 & 1.0 & Chronic stomatitis \\
\hline & 13 & Maltese & 8 & M & 3.1 & 63.1 & & & ND & & Gastric cancer \\
\hline & 14 & Mongrel & 11.2 & M & 18.3 & 15.7 & 78.0 & 6.0 & 15.0 & 1.0 & Mastocytoma \\
\hline & 15 & Shiba & 10 & M & 5.3 & 9.8 & 87.0 & 3.0 & 10.0 & 0.0 & Renal failure \\
\hline $\begin{array}{l}\text { Apparently } \\
\text { healthy }\end{array}$ & $1-6$ & Beagle & 3-5 M4 & $4^{\mathrm{c})}, \mathrm{F} 2^{\mathrm{c})}$ & $12.0 \pm 2.6^{\mathrm{d})}$ & $\begin{array}{c}12.3 \pm 3.0 \\
(6.0-17.0)^{\mathrm{e})}\end{array}$ & $\begin{array}{c}75.5 \pm 5.9 \\
(60-77)\end{array}$ & $\begin{array}{c}14.1 \pm 3.5 \\
(12-30)\end{array}$ & $\begin{array}{c}7.3 \pm 1.8 \\
(3-10)\end{array}$ & $\begin{array}{c}3.1 \pm 2.1 \\
(2-10)\end{array}$ & \\
\hline
\end{tabular}

M: male, F: female, NF: neutered female, NM: neutered male, WBC: white blood cell, Neutro: neutrophils, Lymph: lymphocytes, Mono: monocytes, Eos: eosinophils.

a) Inflammatory diseases were classified into acute and chronic types on the basis of the duration of diseases and pathological findings. b) Not done. c) Number of dogs. d) Each value represents the mean \pm standard deviation of 6 control dogs. e) Data in parentheses represent ranges of normal dogs, referred to as Jain 1986 [3].

Table 2. IL-8 levels in blood plasma samples from dogs

\begin{tabular}{lcc}
\hline Case & $\begin{array}{c}\text { No. of tested } \\
\text { dogs }\end{array}$ & IL-8 $(n \mathrm{~g} / \mathrm{m} l)^{\mathrm{a})}$ \\
\hline Cystitis & 4 & $1.410 \pm 0.200$ \\
Dermatitis & 5 & $0.509 \pm 0.042$ \\
Chronic dermatitis & 1 & $<0.470^{\mathrm{b})}$ \\
Chronic gastritis & 1 & $<0.470$ \\
Chronic stomatitis & 1 & $<0.470$ \\
Gastric cancer & 1 & $0.750 \pm 0.058$ \\
Mastocytoma & 1 & $<0.470$ \\
Renal failure & 1 & $<0.470$ \\
Apparently healthy & 6 & $<0.470$ \\
\hline
\end{tabular}

a) The O.D. values measured by a sandwich ELISA represent the mean \pm standard deviation in the triplicate assay.

b) Less than the lowest detection limit of the sandwich ELISA.

O.D. values at $405 \mathrm{~nm}$ of reacted wells were measured using a microplate reader (Bio Rad, Tokyo, Japan). The appropriate concentrations of capturing and developing antibodies for the detection of cIL-8 in the sandwich ELISA were $4 \mu \mathrm{g} / \mathrm{m} l$ and $1 \mu \mathrm{g} / \mathrm{m} l$, respectively (data not shown). Statistical analysis was carried out by Student's $t$ test.

As shown in Fig. 1, GST ranging from 1 to $250 \mathrm{ng} / \mathrm{m} l$ was not almost detected by this ELISA. cIL- 8 in the fusion protein of GST/cIL-8 was detected in a dose dependent manner. The lowest limit of GST/cIL- 8 detectable by this method was $2 \mathrm{ng}$ of GST/cIL-8 (containing; $0.470 \mathrm{ng} / \mathrm{m} l$ of cIL-8).

To examine the applicability of the sandwich ELISA in clinical cases, IL-8 levels in the plasma samples of apparently healthy dogs and patient dogs with cystitis, dermatitis, chronic gastritis, chronic stomatitis, gastric cancer, mastocytoma or renal failure were determined by the sandwich ELISA. The results summarized in Tables 1 and 2 showed that IL- 8 levels in the plasma samples from apparently healthy dogs were less than $0.470 \mathrm{ng} / \mathrm{ml}$. Higher levels of IL-8 were detected in the plasma samples of dogs with cystitis $(1.410 \pm 0.200 \mathrm{ng} / \mathrm{ml})$, dermatitis $(0.509 \pm$ $0.042 \mathrm{ng} / \mathrm{ml})$, and gastric cancer $(0.750 \pm 0.058 \mathrm{ng} / \mathrm{ml})$ than those with chronic dermatitis, chronic gastritis, chronic stomatitis, mastocytoma, and renal failure $(<0.470 \mathrm{ng} / \mathrm{ml})$.

The present results demonstrated that the sandwich ELISA using polyclonal anti-cIL- 8 antibodies detected the lowest level of $0.470 \mathrm{ng} / \mathrm{m} l$ of cIL- 8 , suggesting that this quantitative method is as almost highly sensitive as that using polyclonal anti-cIL-8 antibodies and monoclonal antirabbit IL-8 antibodies reported by Massion et al. [7]. In this ELISA system for detecting cIL-8, GST in the fusion protein of GST/cIL-8 used as an antigen was not almost detected (Fig. 1). Therefore, high sensitivity and specificity in this ELISA may be due to highly purified antibodies specific for cIL-8, as described previously [11].

An increase in the level of plasma IL-8 is one of possible parameters in inflammatory disorders [5, 12-14]. IL-8 production in tracheal lesions has been reported to be involved in polymorphonuclear cell infiltration in dogs injected intratracheally with the culture supernatant of Staphylococcus aureus [8]. However, there is little information concerning the relationship between IL-8 levels and different types of diseases in dogs. The present study 


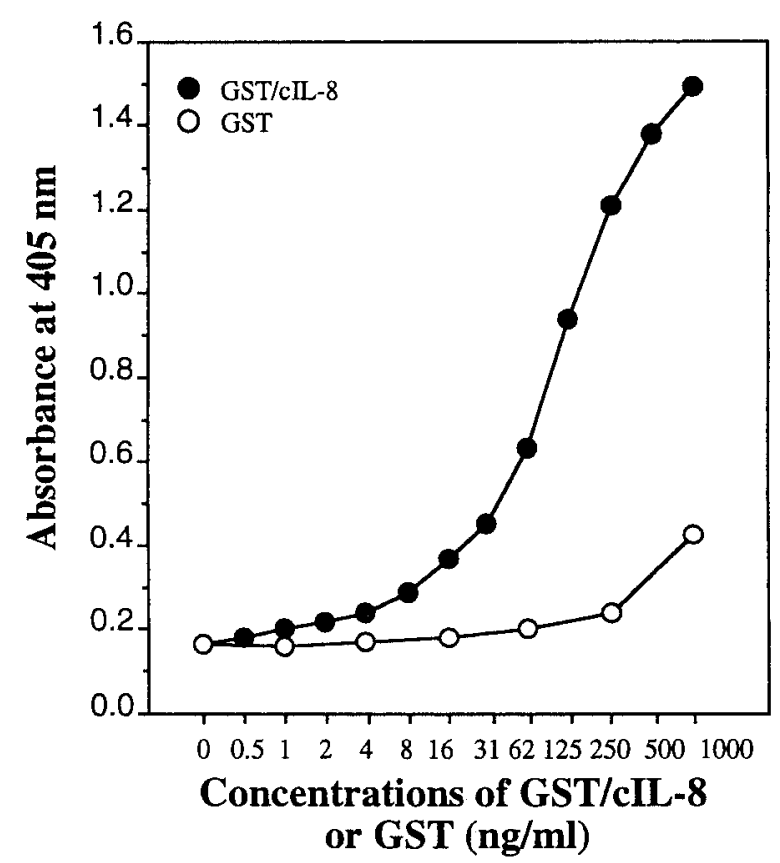

Fig. 1. Detection of GST/cIL-8 by a sandwich ELISA. The wells were coated with polyclonal anti-cIL-8 antibodies (4 $\mu \mathrm{g} / \mathrm{m} l$ ). Serially 2 fold diluted GST/cIL-8 $(\bigcirc)$ or GST $(\bigcirc)$ were applied to the coated wells, and then biotinylated polyclonal anti-cIL-8 antibodies $(1 \mu \mathrm{g} / \mathrm{m} l)$ were added to the wells.

using ELISA demonstrated for the first that the levels of plasma IL-8 in dogs with cystitis, dermatitis and gastric cancer were higher than those in apparently healthy dogs. These results suggest that a higher level of IL- 8 detected by this sandwich ELISA may be useful in diagnosis of inflammatory diseases in dogs. More detailed studies are needed to understand the biological and pathological roles of IL-8 in canine diseases with many different types of inflammatory lesions.

ACKNOWLEDGMENTS. We are grateful to Mrs. Kimiko Yoshinari for her technical assistance. This study was supported in part by the Special Coordination Fund for
Promoting Science and Technology from the Agency of Science and Technology of Japan.

\section{REFERENCES}

1. Harada, A., Sekido, N., Kuno, K., Akiyama, M., Kasahara, T., Nakanishi, I., Mukaida, N., and Matsushima, K. 1993. Int. Immunol. 5: 681-690.

2. Hassfurther, R. L., Canning, P. C., and Geib, R. W. 1994. Vet. Immunol. Immunopathol. 42: 117-126.

3. Jain, N. 1986. pp. 909-939. In: Schalm's Veterinary Hematology, 4th ed. (Jain, N. ed.), Lea and Febiger, Philadelphia, PA, U.S.A.

4. Kasahara, T., Mukaida, N., Shinomiya, H., Imai, M., Matsushima, K., Wakasugi, H., and Nakano, K. 1987. J. Immunol. 138: 1804-1812.

5. Ko, Y.-C., Mukaida, N., Ishiyama, S., Tokue, A., Kawai, T., Matsushima, K., and Kasahara, T. 1993. Infect. Immun. 61: 1307-1314.

6. Lynch III, J. P., Standiford, T. J., Rolfe, M. W., Kunkel, S. L., and Strieter, R. M. 1992. Am. Rev. Respir. Dis. 145: 14331439.

7. Massion, P. P., Hebert, C. A., Leong, S., Chan, B., Inoue, H., Grattan, K., Sheppard, D., and Nadel, J. A. 1995. Am. J. Physiol. 268: L85-L95.

8. Matsumoto, Y., Mohamed, A., Onodera, T., Kato, H., Ohashi, T., Goitsuka, R., Tsujimoto, H., Hasegawa, A., Furusawa, S., Yoshihara, K., Ishikawa, J., Hotta, K., Suzuki, K., and Hirota, Y. 1994. Cytokine 6: 455-461.

9. Matsumoto, Y., Yamagoe, S., Suzuki, K., Hirota, Y., Matsumoto, Y., and Onodera, T. 1995. J. Toxicol. Pathol. 8: 239-244.

10. Mohamed, A., Matsumoto, Y., Furusawa, S., Yoshihara, K., Matsumoto, Y., Onodera, T., and Hirota, Y. 1995. J. Vet. Med. Sci. 57: 603-610.

11. Mohamed, A., Matsumoto, Y., Furusawa, S., Yoshihara, K., Matsumoto, Y., Onodera, T., Suzuki, K., and Hirota, Y. 1996. J. Vet. Med. Sci. 58: 219-224.

12. Seitz, M., Dewald, B., Gerber, N., and Baggiolini, M. 1991. J. Clin. Invest. 87: 463-469.

13. van Zee, K. J., DeForge, L. E., Fischer, E., Marano, M. A., Kenney, J. S., Remick, D. G., Lorwy, S. F., and Moldawer, L. L. 1991. J. Immunol. 146: 3478-3482.

14. Wakefield, D. and Lloyd, A. 1992. Cytokine 4: 1-5. 